\title{
Bioprocesses for biofuels: an overview of the Brazilian case
}

\author{
Monica Caramez Triches Damaso ${ }^{*}$, Cristina Maria Monteiro Machado ${ }^{\dagger}$, Dasciana de Sousa Rodrigues ${ }^{\dagger}$, \\ Silvia Goncalves Belem ${ }^{\dagger}$ and Thais Fabiana Chan Salum ${ }^{\dagger}$
}

\begin{abstract}
Renewables are $46 \%$ in the Brazilian energy matrix, while the world scenario differs from this context to use only $13 \%$ of these resources. The biomass conversion using bioprocess has great potential to be applied in Brazil due to its large agroindustry which can produce a variety of feedstocks and byproducts that can be converted into biofuels and chemicals. The production of first-generation ethanol using sugarcane is a conventional technology in Brazil. This ethanol is the most competitive in the world, and Brazilian production reached 23.64 billion $\mathrm{L}$ in 2012/2013 season. Sugarcane bagasse generated from ethanol production and other biomasses obtained from forest and wood industries, crop residues, and grasses can be deconstructed to obtain sugars. These sugars may be bioconverted into second-generation ethanol and chemicals. Biodiesel is another biofuel that has been produced in Brazil. Although the commercial route to obtain biodiesel uses chemical conversion, there are researches investigating the biochemical route. Furthermore, some topics about microalgae use for biofuels are introduced. Therefore, this paper has the aim to present bioprocesses used in bioenergy production and the Brazilian overview on the conventional technology of first-generation sugarcane ethanol production. Moreover, bench studies and demonstration facilities that have been developed in the country regarding the advanced technologies are presented.
\end{abstract}

Keywords: Biomass; Cellulose; Sugarcane; Oilseeds; Byproducts; Algae; Ethanol; Biodiesel; Chemicals

\section{Introduction}

Brazil is a continental country and, for this reason, has different kinds of climate, soil, and rainfall conditions, which enable the production of diverse agricultural cultures that have shown significant increasing over the last years. These cultures and the byproducts and residues generated during their production chain allow this country to obtain a variety of commercial products that are used in different industrial sectors such as food, cosmetic, pharmaceutical, beverage, oleochemical, bioproducts, and biofuels.

The conversion of any type of raw material to end products can be carried out using physical, biochemical, or chemical process. The unit operations and unit processes employed in biochemical and chemical process are similar. However, the main differences between them are the use of living systems and milder conditions of temperature and $\mathrm{pH}$ by the former $[1,2]$.

\footnotetext{
* Correspondence: monica.damaso@embrapa.br

${ }^{\dagger}$ Equal contributors

Embrapa Agroenergy, Parque Estação Biológica S/N, Av. W3 Norte (final), 70770-901, Brasília, DF, Brazil
}

In bioprocesses, enzymes, microorganisms, mammalian or plant cells, wild or recombinant, can be used to convert feedstocks into useful products of great interest to society $[1,3]$. These products can be antibiotics, biofuels, protein, and sugar hydrolysates, enzymes, vaccines, biopesticides, beverage, organic acids, and others. In some cases, the bioprocesses are the only alternative to obtain some of them or are extremely advantageous when compared to routes involving chemical synthesis. Notwithstanding biochemical processes can be used in different industries, this manuscript emphasizes only bioprocesses used to obtain biofuels and bioproducts from biomass to energy and focus mainly in the Brazilian scenario.

The technologies applied to convert raw materials into end products can be divided in conventional and advanced technologies. The latter can be carried out in process of validation or in bench or pilot-scale development. These concepts can also be applied in the bioenergy sector [4]. Regarding the researches in Brazil, four processes will be highlighted: first-generation ethanol

\section{黛 Springer}


production from sugarcane, lignocellulosic biomass deconstruction, biodiesel production by enzymatic route, and biofuels from microalgae. Sugarcane ethanol is classified as conventional technology, whereas the others are advanced.

Although information about these processes in Brazil is available, seldom, some of them are published internationally through a technical overview. Therefore, this paper has the aim to present a bioenergy Brazilian overview about bioprocess involving conventional and advanced technologies.

\section{Review}

\section{Sugarcane ethanol}

Today, ethanol is the main biofuel used in the world with ever-increasing opportunity for expansion of production and consumption. Brazil is the second largest producer of ethanol in the world [5], using mostly sugarcane as feedstock, which from the economic, environmental, and energy points of view, represents the best alternative for this biofuel production [6,7]. Three hundred eighty-nine Brazilian mills and distilleries crushed a total of 589 million tons of sugarcane and produced 23.64 billion $\mathrm{L}$ of ethanol as well as 38.34 million tons of sugar in 2012/2013 season. The estimate for the 2013/ 2014 season is 27.17 billion of liters, a growth of almost $15 \%[8]$.

The progress of the Brazilian ethanol industry has been based on private and public sector investments during the last 40 years, leading to an upright path of innovation, diffusion, increased productivity, and lowered agricultural and industrial production costs [9]. Furthermore, in the last years, there has been significant diversification in the composition and origin of the capital invested in this industry. Originally, almost exclusively based on family businesses, currently, capital investments are being made by a range of companies (Cosan, Costa Pinto, Guarani, Nova America, and Sao Martinho) as well as by strategic national (Votorantim, Vale, Camargo Correa, Odebrecht, Petrobras) and foreign investors [10]. The latter group includes investors such as Tereos (Lille, France), Louis Dreyfus (Rotterdam, Netherlands), Cargill (Minneapolis, MN, USA), Abengoa (Seville, France), Pantaleon Sugar Holdings (Guatemala Ciudad, Guatemala), Noble (Gloucester Road, Hong Kong), Clean Energy (Houston, TX, USA), Shree Renuka (Mumbai, India), Infinity Bio Energy (São Paulo, SP, Brazil), and Sojitz (Tokyo, Japan). In 2012, international groups reached $25 \%$ share in production, up from zero in 2000 and $12 \%$ in $2008 / 2009$ [11,12].

Ethanol production from sugarcane as shown in Figure 1 is a very well established process with few differences between plants, mostly in the type and quality of equipment, operational controls, and especially in the management level [13]. In the beginning stages of this industry in Brazil, it had an overall efficiency of $66 \%$; today, it reaches over $86 \%$ on average. With such high levels of performance already achieved, and taking into account that the industrial sector represents only $29 \%$ of the total ethanol production costs, it is a challenge to make further significant gains [9].

Sugarcane cannot be stored for more than a few days, and mills operate only during the harvest period. The initial operations in the processing, reception, preparation, and extraction of sugarcane juice are very important due to the required investment, operational and maintenance costs, and high energy consumption. The traditional harvest system includes the previous burning of the sugarcane crop and the manual cutting of the whole stalk. This is being progressively substituted by mechanized harvest of green chopped sugarcane, without burning $[10,14]$. The transportation system is based on trucks. After the sampling of material for quality assay, the stalks are washed, if they were manually harvested, or dry cleaned, in the case of mechanical harvesting.

Juice extraction is made traditionally by roll mills arranged in four to seven sets or, more recently, by diffusers. Both systems are efficient; nonetheless, diffusers, if operated in their best conditions, present less energy consumption, lower maintenance costs, and can be more easily automatized. The main objective of the milling process is to extract the largest possible amount of sucrose from the cane. Besides that, the bagasse produced feeds the boilers, which supply electricity and steam for the process to be self-sufficient and, in some cases, can even deliver excess electricity to the grid [15].

After extraction, the juice is filtered and chemically treated for soluble solids and impurities removal. Subsequently, the juice is evaporated to balance its sugar concentration, generating a sugary solution which is ready to be fermented.

The Brazilian fermentation process has been significantly improved during the years, increasing from $82 \%$ of theoretical stoichiometric rate conversion in 12 to $16 \mathrm{~h}$ to a current average of $90.5 \%$ in 8 to $9 \mathrm{~h}$ [16]. The most common fermentation process in Brazil is characterized by the use of very large tanks ( 0.5 to 3 million $\mathrm{L}$ ) and intensive recycle of the yeast cells (>90\%), resulting in considerably high cell density inside the fermenter ( $10 \% w / v$ to $17 \% w / v$, wet basis), which contributes to the very short fermentation time [17]. Around $85 \%$ of these distilleries operate in fed-batch processes, and just $15 \%$ in continuous fermentation processes [18]. Ethanol plants traditionally utilized baker's yeast as starter cultures, because of its low cost and availability. However, as the fermentation conditions are very stressful (high temperature, high ethanol concentration, osmotic stress due to sugar 


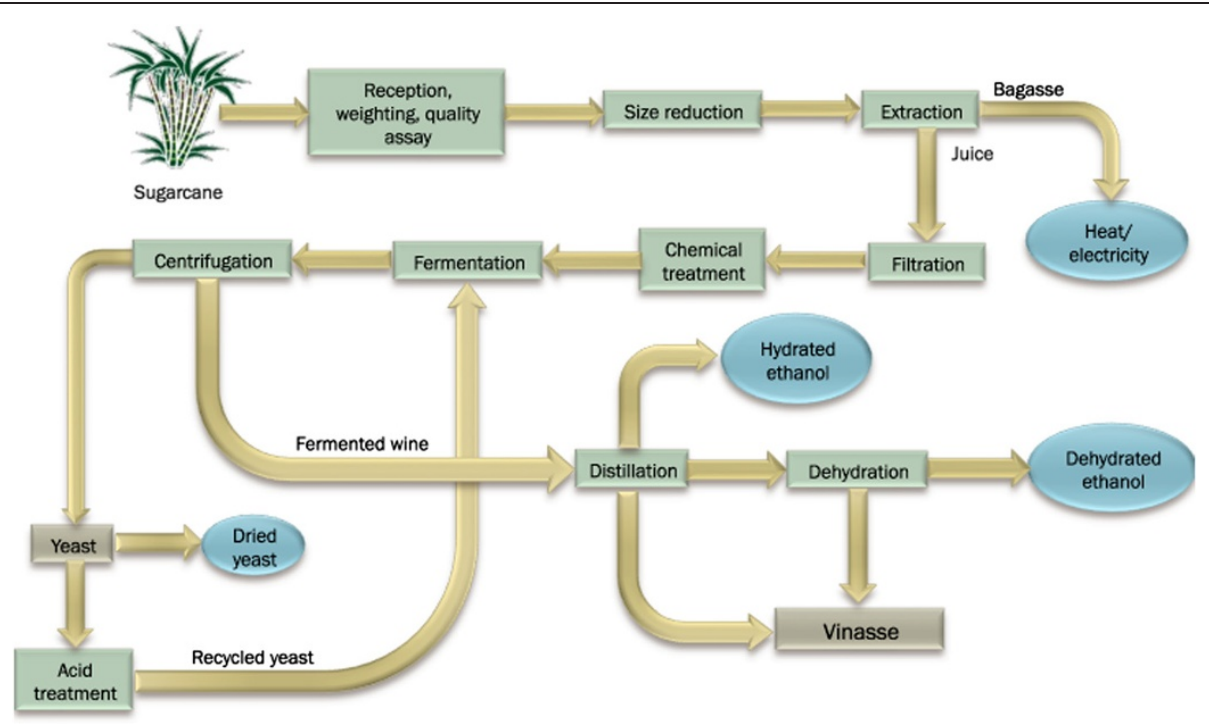

Figure 1 Flowchart of sugarcane ethanol production in Brazil.

and salts, acidity, and bacterial contamination), the starter culture is unable to compete with indigenous yeasts that contaminate the industrial process. For this reason, in the last 15 years, most part of mills have been using strains previously selected in the same mills, as BG-1, CAT-1, PE-2, and SA-1. After fermentation, the yeasts are recovered and treated with sulfuric acid to be reused in fermentation, while the wine is sent to distillation $[19,20]$.

In distillation, ethanol is initially recovered in hydrated form $\left(96^{\circ} \mathrm{GL}\right)$, producing vinasse or stillage as residue, at a ratio of 10 to $13 \mathrm{~L}$ per liter of hydrated ethanol produced. This vinasse is now managed as a soil nutrient source, and its application has been optimized within environmental control limits [21]. Hydrated bioethanol can be stored as final product or may be sent to the dehydration process, as it is an azeotropic mixture and its components cannot be separated by distillation only. The most commonly used technology in Brazil for this purpose is dehydration with addition of cyclohexane, forming a ternary azeotropic mixture. The second method, of more recent industrial use, is extractive distillation with monoethyleneglycol (MEG), which stands out as provider of lower energy consumption. The third method is dehydration by adsorption with molecular sieves [10].

Even with this very efficient process and high production of sugarcane, Brazil has been importing ethanol. In season 2012/2013, the imported amount was 302 million L, mostly from the USA. For this reason, complementary cultures to sugarcane are being studied, as sweet sorghum, which could be produced off season, and cellulosic ethanol, from cane bagasse or from dedicated crops as tropical forages.
Deconstruction of lignocellulosic biomass and its uses Cellulosic biomass can be obtained from products and byproducts of forest and wood industries, agricultural and energy crop residues, and grasses. The plant cell wall is composed mainly by polymers as cellulose, lignin, and hemicellulose. In general, cellulose polymer is the most abundant, representing from $34 \%$ to $50 \%$ of dry weight, followed by hemicellulose (19\% to $34 \%)$ and lig$\operatorname{nin}(11 \%$ to $30 \%)$ [22]. The proportion of each polymer in lignocellulosic biomass varies considerably among plant species as well as within the same species, being dependent on the tissue type, environmental factors, and developmental stage [23].

The deconstruction of lignocellulosic biomass is based on the hydrolysis of polysaccharides and degradation of lignin. Hydrolysis of polysaccharides generates simple sugars that can be fermented into ethanol or can be transformed in chemicals. The degraded lignin also can be used to produce fuels and chemicals. Its main steps are pretreatment and enzymatic hydrolysis.

Pretreatment of lignocellulosic materials is an essential step in the deconstruction of physical and chemical barriers that make the material resistant to enzymatic hydrolysis. Pretreatment can break down lignin and hemicellulose bonds, disrupt the crystalline arrangement of cellulose, increase digestibility and cell wall porosity, and improve accessibility to enzymes during hydrolysis [24].

For the pretreatment of lignocellulose, chemical, physical, biological, or combinations of these methods can be used, depending on the required degree of separation and the intended purpose of the process. Examples of types of pretreatment are steam explosion, acid hydrolysis, alkaline treatment, and biological treatment. 
The enzymes used for hydrolysis can be divided into two types: hydrolytic and oxidative systems. The first group makes the hydrolytic degradation of polysaccharides, cellulases and hemicellulases mainly, and the oxidative promotes lignin degradation $[23,25,26]$.

Fuel ethanol is the most studied product from deconstructed biomass. Hydrolysis of cellulose generates glucose that is readily fermentable. However, hydrolysis of hemicellulose mainly provides pentoses (xylose and arabinose), carbohydrates that cannot be directly fermentable by wild Saccharomyces cerevisiae strains. The bioconversion of these pentoses into ethanol is one of the most important challenges to enable the lignocellulosic ethanol production. Besides that, hemicellulose releases hexoses such as glucose, mannose, and galactose.

Besides ethanol, sugars generated by biomass deconstruction can also be used to produce building block chemicals via biological or chemical conversions. Building blocks are molecules with multiple functional groups that can be subsequently converted to a number of highvalue bio-based chemicals or materials. Examples of sugar-based building blocks are levulinic acid, lactic acid, succinic acid, glycerol, sorbitol, and xylitol [27].

The degraded lignin also can be recovered and used in (a) thermochemical processes for the production of energy and fuels, such as combustion, gasification, and pyrolysis; (b) production of macromolecules as carbon fiber, polymer modifiers, adhesives, and resins; and (c) production of aroma chemicals such as phenol, toluene, syringil, guaicyl, and benzene [28].

Over the last years, many research institutes in Brazil have been working on biomass deconstruction, and the number of published papers has increased every year. In a search on the website Web of Science, using 'Brazil' as address and 'enzymatic hydrolysis' and 'biomass' as topics, 128 papers were displayed. In 2010, only 13 papers were published in Brazil, but in 2013, the number of papers was 50, i.e., it increased more than three times (Figure 2). The majority of the papers are related to lignocellulosic ethanol production. Institutions that publish most in this field in Brazil are University of São Paulo, State University of Campinas, and Federal University of Rio de Janeiro [29].

In another search on the Web of Science, using 'Brazil' as address and 'second generation ethanol' or 'lignocellulosic ethanol' as topics, 210 papers were found. Brazil appears as the third country that publishes most in this subject (despite representing only $6.4 \%$ of all papers published), after USA and China (Figure 3). The majority of the papers are related to the production and utilization of enzymes for enzymatic hydrolysis of biomass, followed by biomass pretreatment. Brazilian institutions that publish most in this field are São Paulo University, State University of Campinas, Federal University of Rio de Janeiro, Federal

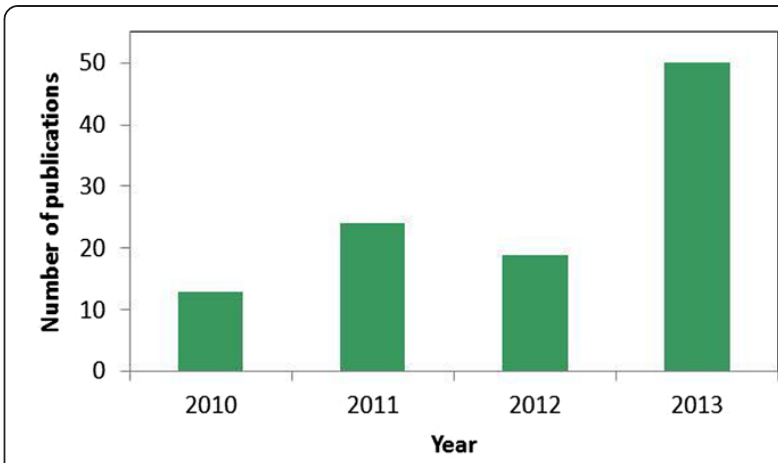

Figure 2 Number of publications from 2010 to 2013. The publications were displayed after a search on Web of Science, using 'Brazil' as address and 'enzymatic hydrolysis' and 'biomass' as topics [29].

University of São Carlos, and Brazilian Bioethanol Science and Technology Laboratory (CTBE) [29].

In Brazil, in addition to researches developed in universities, there are some research institutes that study biomass processing and its utilization. Examples are Sugarcane Technology Center (CTC), CTBE, and Brazilian Agricultural Research Corporation (Embrapa). CTC and CTBE work mostly with sugarcane and its products. Embrapa develops research in different biomass breeding and processing.

The first company of commercial cellulosic ethanol production in Brazil is GranBio, a Brazilian biotechnology industrial company. This company licensed PROESA technology from Vercelli, Italy. The facility, which is being installed in Alagoas, will have the capacity of 82 million L of ethanol per year and should start in 2014 [30,31].

The PROESA technology focuses on obtaining highquality fermentable sugars (xylose and glucose) for ethanol and other chemical production. The company Beta Renewables (Tortona, Italy) is in charge of the development and licensing of the technology.

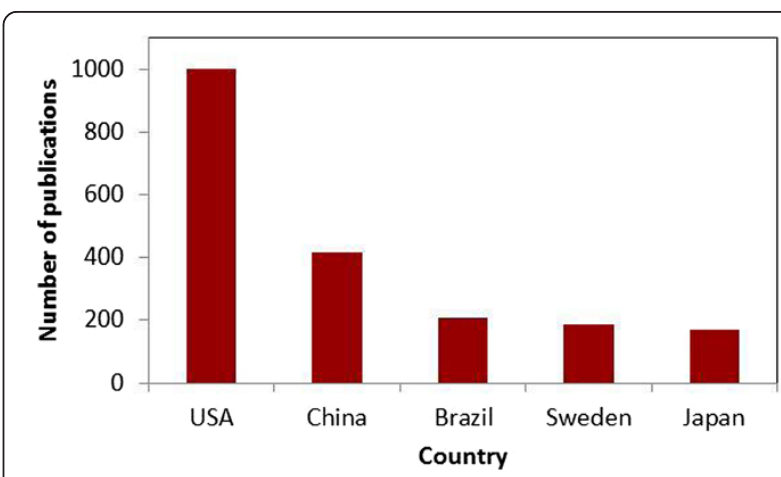

Figure 3 The top five countries publishing on the topics 'second-generation ethanol' or 'lignocellulosic ethanol'. This data is according to a search on Web of Science [29]. 
The steps for obtaining sugars by PROESA technology are: 1) steam pretreatment (smart cooking); 2) enzymatic hydrolysis; and 3) fermentation using an engineered strain to convert C5 and C6 sugars into ethanol. The lignin removed by the process can be used for energy generation.

Another initiative in Brazil to produce second-generation ethanol on a commercial scale has been implemented by Raizen Energia S/A (São Paulo, Brazil). The company will use Iogen Energy's technology (Ottawa, Canada), which is similar to that of PROESA's. The main difference between them is that the latter uses simultaneous saccharification and fermentation, while Iogen's technology has separated saccharification and fermentation. The plant will be located in Piracicaba (São Paulo) and may produce up to 40 million $\mathrm{L}$ of second-generation ethanol a year. The ethanol production should start in 2014 $[32,33]$. Despite researches and industrialization initiative on the theme of deconstruction and use of biomass, studies on synthesis of high-added-value bioproducts are still needed, in order to allow better use of all biomass components.

\section{Biodiesel production by enzymatic route}

The Brazilian biodiesel production has increased since 2005 and reached more than 2.9 million $\mathrm{m}^{3}$ in 2013 [34]. In an industry that is still in consolidation process, the ranking of the leading producers of biodiesel in the world varies from a year to the other. In 2012, Brazil was the third largest world producer of biodiesel, overcome by the USA and Germany.

Blending of $5 \%$ of biodiesel into petrodiesel (B5) became mandatory in Brazil in 2010. Since this year, oil and biodiesel producers have expected an increase in this percentage. In June 2014, the Brazilian government announced the extension of this blending to 7\% (B7) until the end of this year. This new overview can increase the opportunity for expansion of biodiesel production and consumption.

Soybean is the main raw material used to produce biodiesel worldwide, while canola is the second one and palm oil, which consumption has increased over the last few years, ranked as third [34]. The Brazilian scenario is different: soybean is the first raw material, bovine fat is the second, and the remainder positions are occupied by diverse sources, as cottonseed, frying oil, and palm oil [35].

Figure 4 presents the contribution of each oil source used in the Brazilian biodiesel production in 2013 [35]. Soybean is the main raw material used.

Despite the differences between the raw materials used, chemical transesterification is the route applied worldwide in commercial biodiesel production, using vegetable oil or fat, methanol and chemical alkaline catalyst. However,

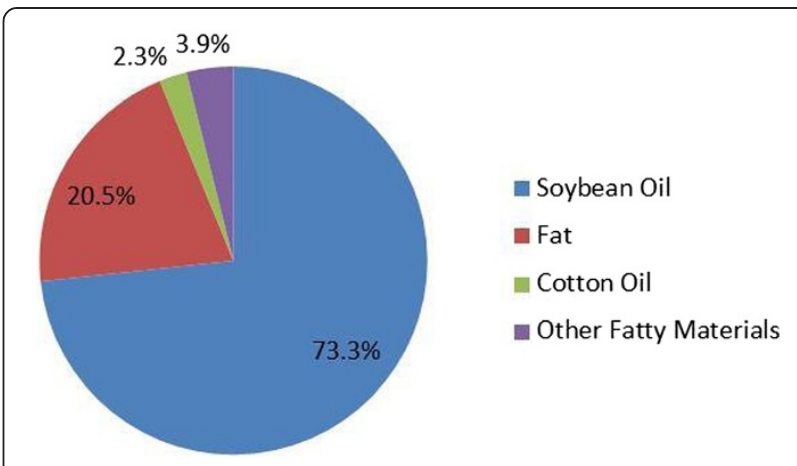

Figure 4 Percentages of raw materials used in the production of Brazilian biodiesel in 2013 [35].

there are several advantages of the use of enzymatic catalysis for biodiesel production. Lipases can esterify the free fatty acids contained in frying oils and animal fats, which allow being more technically feasible than chemical route. Additionally, glycerol from biodiesel production can be easily recovered without complex treatment, the enzyme may be recycled, and the process requires less energy and has significant reduction in the amount of waste generated [36,37].

Despite the advantages of enzymatic catalysis, there are obstacles that prevent enzymatic process to be used commercially for biodiesel production: the high lipase price, the long time necessary for the synthesis reaction of biodiesel, and possible inhibition and/or denaturation of the enzyme by the alcohol $[37,38]$. There are some reports of industrial-scale production of biodiesel by enzymatic catalysis from Lvming Co. Ltd. and Hainabaichuan Co. Ltd., both companies in Shanghai, China [39], and some companies as Novozymes (Bagsvaerd, Denmark) [40] and the Transbiodiesel Ltd. (Shfar-Am, Israel) [41] have invested in search for biocatalysts to biodiesel production.

On January 2014, the American Blue Sun Energy Company (Greensboro, NC, USA) inaugurated a commercialscale plant, in St. Joe, Missouri, using enzymatic biodiesel processing technology developed by Novozymes. This plant has a production capacity of $135,500 \mathrm{~m}^{3}$ per year of biodiesel. This is the first commercial-scale plant in the world [42].

Many Brazilian teams in universities and in research institutes, including Embrapa Agroenergy, Alberto Luiz Coimbra Institute-Graduate School and Research in Engineering (COPPE), and University of São Paulo, have carried out works aiming to develop biotechnological route for the production of biodiesel. The major challenges to establish a commercial route are the production of resistant lipase to severe conditions of biodiesel production medium and the reduction of lipases production cost. 


\section{Microalgae for biofuels}

Species of microalgae as Chlorella vulgaris, Spirulina platensis, Dunaliella salina, and Haematococcus pluvialis are commercially cultivated in small and medium scales, with production in the range of tens to hundreds of tons of biomass per year, in a total world production of about 10,000 tons/year [43]. There are numerous commercial applications of microalgae, such as enhancing the nutritional value of food and animal feed, aquaculture, and cosmetics. Moreover, they are cultivated as a source of highly valuable molecules as polyunsaturated fatty acid oils (PUFA), which can be added to infant formulas and nutritional supplements and as pigments to be used as natural dyes $[44,45]$.

In recent years, microalgae have become a focus in biofuel research, mainly as source of oil for biodiesel production or for direct production of metabolites as hydrocarbons and ethanol. A number of attempts have been made to produce algae for biofuel commercially worldwide.

Microalgae research and production in Brazil started in 1970, and currently, the only commercial production is for aquiculture, in several small-scale companies mostly in the northeastern region of the country [46]. Nonetheless, Brazil has a great potential for large-scale microalgae production, given its large tropical coastal area. Several research efforts on the isolation, characterization, and domestication of highly productive algal strains from Brazilian biodiversity are currently under way, mostly with focus to biodiesel production [47]. Additionally, two commercial plants have been announced in 2012. (i) One of them, Solazyme Bunge Renewable Oils (San Francisco, CA, USA), is a joint venture of Solazyme Inc. with Bunge Global Innovation (White Plains, NY, USA), the first commercial-scale renewable oil production facility, adjacent to Bunge's Moema sugarcane mill in São Paulo state. Their process is based on the transformation of a range of low-cost plant-based sugars into high-value oils using genetically transformed microalgae, initially into three target markets: fuels and chemicals, nutrition, and skin and personal care [48]. (ii) The other, See Algae Technology (SAT; Vienna, Austria), is an Austrian developer of equipment for the commercial production of algae, with JB which a Brazilian ethanol producer group. The plant will produce algal biomass from natural and genetically modified strains of algae, using reactors of up to $5 \mathrm{~m}$ in height, with a solar prism that transfers light to reactors through optical fibers, connected to the chimneys of the sugarcane mill nearby using the carbon dioxide generated by the fermentation process to feed the algae. One of the products planned for this process will be feedstock for animals, providing an alternative to soybeans. The process also yields algal lipids that can be used to make biodiesel and biochemicals [49].
Albeit microalgal biofuels have the potential to be far superior to biofuels derived from terrestrial plants and have the potential to be produced sustainably [50], significant improvements in the efficiency, cost structure, and ability to scale up algal growth and lipid extraction must be made to produce commercially viable biofuel [51].

\section{Conclusions}

Among the bioprocesses presented, only sugarcane ethanol production is currently applied in commercial scale in Brazil. Indeed, the country is the second largest producer of ethanol in the world, and the first-generation technology process is carried out for this production using sugarcane as feedstock. Regarding the economic, environmental, and energy aspects, it represents the best alternative for this biofuel production. However, the amount of ethanol is insufficient to supply domestic demand. In order to solve this problem, two strategies are being evaluated: use of other raw materials to produce first-generation ethanol and the production of cellulosic ethanol from different biomass using second-generation technology.

There are many companies producing enzymes for biomass deconstruction and biodiesel production by enzymatic route. Several universities and research institutes have been screening microorganisms and optimizing bioprocess for the development of enzyme cocktails technically and economically feasible. However, there are still some challenges in enzyme cost reduction and in the improvement of activity and stability of these enzymes, mostly in severe conditions.

The use of microalgae for biofuel production has also been evaluated worldwide. Brazil has characteristics such as climate, nutrients, and $\mathrm{CO}_{2}$ sources which are important to establish this process. Nevertheless, significant improvements must be made to produce commercially viable biofuels from this feedstock.

Certainly, the best opportunity to turn the advanced technologies described in this paper into a commercial reality is to work in a biorefinery context using all feedstock to generate a diversity of products as biofuels, bioproducts, and energy.

\section{Competing interests}

The authors declare that they have no competing interests.

\section{Authors' contributions}

MCTD wrote the Abstract and the 'Introduction' and the 'Biodiesel production by enzymatic route' sections. CMMM wrote the 'Sugarcane ethanol' and the 'Microalgae for biofuels' sections. SGB participated in the writing of the 'Sugarcane ethanol' section. DSR wrote the parts concerning 'Deconstruction of lignocellulosic biomass and its uses' section. TFCS wrote the 'Deconstruction of lignocellulosic biomass and its uses' and the 'Biodiesel production by enzymatic route' sections. All authors participated in writing the conclusions and in the design of the study and approved the final version.

\section{Acknowledgements}

We would like to thank Maria Goreti Braga for the graphical abstract design and José Dilcio Rocha for the critical text review. This work was supported 
by grants from the Brazilian Agricultural Research Corporation (Embrapa), Brazilian National Council for Scientific and Technological Development (CNPq), and the Brazilian Development Bank (BNDES).

\section{Received: 31 March 2014 Accepted: 1 July 2014} Published online: 29 August 2014

\section{References}

1. Bungay HR, Tsao GT, Humphrey AE (1984) Biochemical engineering. In: Perry RH, Green D (eds) Perry's handbook for chemical engineers. McGraw-Hill, New York, p 27

2. Rao DG (2005) Introduction to biochemical engineering. McGraw-Hill, New York, http://books.google.com.br/books?id=5RUMRF5jpIUC\&pg=PA416\&lpg =PA416\&dq=bailey+j.e.+and+ollis+d.f.+biochemical+engineering +fundamentals\&source $=$ bl\&ots $=$ TNcYKIHbU2\&sig $=Z j k C J X 0 \circ D M H 2-$ Ra0QUeCXXrU0_kU\&hl=pt-BR\&sa=X\&ei=2nfzUpv4FuTAyAHN4YGoCw\&ved=0CD4Q6AEwAg\# $v=$ onepage $\& q=$ bailey\%20j.e.\%20and\%20ollis\%20d.f. \%20biochemical\%20engineering\%20fundamentals\&f=false

3. Aiba S, Humphrey AR, Millis NF (1965) Biochemical engineering. University of Tokyo Press, Tokyo, Japan

4. Bacovsky D, Ludwiczek N, Ognissanto M, Wörgetter M Commercializing $1^{\text {st }}$. and $2^{\text {nd }}$-generation liquid biofuels. Status of advanced biofuels demonstration facilities in 2012. A report to IEA Bioenergy Task 39. IEA Bioenergy, USA, http://demoplants.bioenergy2020.eu/files/ Demoplants_Report_Final.pdf

5. Renewable Fuels Association (2013) Industrial statistics. World Fuel Association, Washington, DC, USA, http://www.ethanolrfa.org/pages/ statistics

6. Chum HL, Warner E, Seabra JE, Macedo IC (2013) A comparison of commercial ethanol production systems from Brazilian sugarcane and US corn. Biofuels Bioprod Bioref 8:205-223, http://dx.doi.org/10.1002/bbb.1448

7. Crago CL, Khanna M, Barton J, Giuliani E, Amaral W (2010) Competitiveness of Brazilian sugarcane ethanol compared to US corn ethanol. Energy Policy 38(11):7404-7415

8. Companhia Nacional de Abastecimento (2013) Acompanhamento da Safra Brasileira: Cana-de-Açúcar, Safra de 2013/2014, Segundo levantamento, Agosto/2013. Conab, Brasília, p 19

9. Molinari HBC, Machado CMM (2011) Brazil's sugarcane industry: growing innovation technology \& efficiency. Sugar J 74(3):8-13

10. Banco Nacional de Desenvolvimento Econômico e Social (2009) Sugarcanebased bioethanol: energy for sustainable development, 1st edn. CGEE-BNDES, Rio de Janeiro, Brazil, p 305

11. Economic Commission for Latin America and the Caribbean (ECLAC) (2012) Foreign direct investment in Latin America and the Caribbean. United Nations Publications, Santiago, p 138

12. International Sugar Organization (2012) Outlook of sugar and ethanol production in Brazil. ISO, London, p 45

13. Centro de Gestão e Estudos Estratégicos (2009) Bioetanol combustível: uma oportunidade para o Brasil. CGEE, Brasília, p 536, ISBN - 978-85-60755-15-8

14. De Fiqueiredo EB (2011) Greenhouse gas balance due to the conversion of sugarcane areas from burned to green harvest in Brazil. Agr Ecosystems Environ 141(1):77-85

15. Van den Wall Bake JD, Junginger M, Faaij A, Poot T, Walter A (2009) Explaining the experience curve: cost reductions of Brazilian ethanol from sugarcane. Biomass Bioenergy 33(4):644-658

16. Programa de Educação Continuada em Economia e Gestão de Empresas (PECEGE) (2011) Custos de produção de cana-de-açúcar, açúcar e etanol no Brasil: acompanhamento da safra 2010/2011 - Centro-Sul. USP, ESALQ, PECEGE, Piracicaba, p 63

17. Basso LC, Amorin HV, Oliveira AJ, Lopes ML (2008) Yeast selection for fuel ethanol production in Brazil. Fems Yeast Res 8:1155-1163

18. Godoy A, Amorim HV, Lopes ML, Oliveira AJ (2008) Continuous and batch fermentation processes: advantages and disadvantages of these processes in the Brazilian ethanol production. Int Sugar J 110:175-181

19. Antonangelo ATB, Alonso DP, Ribolla PE, Colombi D (2013) Microsatellitemarker based assessment of the biodiversity of native bioethanol yeast strains. Yeast 8:307-317

20. Amorim HV, Lopes ML, Oliveira JVC, Buckeridge M, Goldman GH (2011) Scientific challenges of bioethanol production in Brazil. Appl Microbio Biotechnol 91(5):1267-1275
21. Walter A, Galdos MV, Scarpare FV, Leal MRLV, Seabra JEA, Da Cunha MP, De Oliveira COF (2014) Brazilian sugarcane ethanol: developments so far and challenges for the future. Wiley Interdisciplinary Reviews: Energy and Environment 3(1):70-92

22. Cagnon B, Py X, Guillot A, Stoeckli F, Chambat G (2009) Contributions of hemicellulose, cellulose and lignin to the mass and the porous properties of chars and steam activated carbons from various lignocellulosic precursors. Bioresource Technol 100:292-298

23. Quiroz-Castañeda RE, Folch-Mallol $J$ (2011) Plant cell wall degrading and remodeling protein. Biotecnol Apl 28:205-215

24. Masarin F, Gurpilhares DB, Baffa DC, Barbosa MHP, Carvalho W, Ferraz A, Milagres AMF (2011) Chemical composition and enzymatic digestibility of sugarcane clones selected for varied lignin content. Biotechnol Biofuels 4:55

25. Rastegari AA, Bordbar AK, Mehnati-Najafabadi V (2010) Conformational changes and sequence analysis in cellulase from Aspergillus niger with cationic surfactant. Cellulose 17:1212-1225

26. Alvira P, Tomas-Pejeo E, Ballesteros M, Negro NJ (2010) Pretreatment technologies for an efficient bioethanol production process based on enzymatic hydrolysis: a review. Bioresource Technol 101(13):4851-4861

27. Bozell JJ, Petersenb GR (2010) Technology development for the production of biobased products from biorefinery carbohydrates - the US Department of Energy's "Top 10" revisited. Green Chem 12:525-728

28. Bozell JJ, Holladay JE, Johnson D, White JF (2007) Top value-added chemicals from biomass volume II-results of screening for potential candidates from biorefinery Lignin. Department of Energy, USA, Report Produced by Staff at Pacific Northwest National Laboratory (PNNL) and the National Renewable Energy Laboratory (NREL) for the U.S. Department of Energy

29. Web of Science http://apps.webofknowledge.com.ez103.periodicos.capes gov.br. Accessed February 25, 2014

30. GranBio http://www.granbio.com.br/produtos/biocombustiveis. Accessed March 10, 2014

31. International Energy Agency (2012) Annual report. IEA-International Energy, Paris, FR, https://www.iea.org/publications/freepublications/publication/ IEA_Annual_Report_publicversion.pdf

32. logen Corporation (2014) Implementing a proven process_Costa Pinto Project. logen Corporation, Ottawa, http://www.iogen.ca/raizen-project/ index.html

33. Raízen (2012) Produção de etanol. Raízen, São Paulo, http://www. transbiodiesel.com/technology/technology-overview

34. BiodieselBR (2012) Produção global de biodiesel cresceu 65\% em cinco anos. Biodieselbr Online Ltda., Mossunguê, http://www.biodieselbr.com/noticias/inter/ argentina/producao-biodiesel-cresceu-65-cinco-anos-290114.htm

35. Ministério de Minas e Energia (MME) (2014) Boletim Mensal de Combustíveis Renováveis (Fev). MME, Brasília D.F., Brazilhttp://www.mme.gov.br/spg/galerias/ arquivos/publicacoes/boletim_mensal_combustiveis_renovaveis/Boletim_ DCR_nx_073_-_fevereiro_de_2014.pdf

36. Fjerbaek L, Christensen KV, Norddahl B (2009) A review of the current state of biodiesel production using enzymatic transesterification. Biotechnol Bioeng 102(5):1298-1315

37. Salum TFC, Villeneuve P, Barea B, Yamamoto Cl, Cocco LC, Mitchell DA Krieger N (2010) Synthesis of biodiesel in column fixed-bed bioreactor using the fermented solid produced by Burkholderia cepacia LTEB11. Process Biochem 45(8):1348-1354

38. Gog A, Roman M, Tosa M, Paizs C, Irimie FD (2012) Biodiesel production using enzymatic transesterification-current state and perspectives. Renew Energ 39(1):10-16

39. Tan TW, Lu JK, Nie KL, Deng L, Wang F (2010) Biodiesel production with immobilized lipase: a review. Biotechnol Adv 28(6):937-937

40. Novozymes (2014) Bioenergy - the future of energy. Novozymes, Bagsvaerd, http://www.novozymes.com/en/solutions/bioenergy/Pages/default.aspx

41. Transbiodiesel Ltd. (2013) Technology overview. Transbiodiesel Ltd. Shfar-Am, http://transbiodiesel.com/technology-overview/

42. Zimmcomm New Media, LLC (2012) Domestic Fuel. Blue Sun opens most advanced biodiesel plant. Zimmcomm New Media, LLC, Cantonment, http://domesticfuel.com/2014/01/20/blue-sun-opens-most-advancedbiodiesel-plant/

43. Benemann JR (2010) Microalgae biomass and biofuels economics. In: Carioc JOB (ed) International microalgae and biofuels workshop. Brazilian Network on Green Chemistry, Fortaleza, Brazil, pp 49-80

44. Spolaore P, Joannis-Cassan C, Duran E, Isambert A (2006) Commercial applications of microalgae. J Biosci Bioeng, Japan, 101:87-96 
45. Pulz O, Gross W (2004) Valuable products from biotechnology of microalgae. Appl Microbiol Biotechnol 65(6):635-648

46. Lourenço SO (2006) Cultivo de microalgas marinhas - princípios e aplicações. RiMa, São Carlos

47. Quirino BF, Brasil BSAF, Laviola BG, Mendonça S, Almeida JRM (2014) Critical analysis of feedstock availability and composition and new potential resourcesfor biodiesel production in Brazil. In: da Silva SS, Chandel AK (eds) Biofuels in Brazil. Springer, Switzerland, In press

48. Solazyme, Inc. http://solazyme.com/media/. Accessed January 18, 2014

49. SEE ALGAE Technology http://www.seealgae.com. Accessed January 18, 2014

50. Chisti Y (2008) Response to Reijnders: do biofuels from microalgae beat biofuels from terrestrial plants? Trends Biotechnol 26(7):351-352

51. Singh A, Olsen SI (2011) Critical analysis of biochemical conversion, sustainability and life cycle assessment of algal biofuels. Appl Energy 88:3548-3555

doi:10.1186/s40538-014-0006-0

Cite this article as: Damaso et al:: Bioprocesses for biofuels: an overview of the Brazilian case. Chemical and Biological Technologies in Agriculture 2014 1:6.

\section{Submit your manuscript to a SpringerOpen ${ }^{\circ}$ journal and benefit from:}

- Convenient online submission

- Rigorous peer review

- Immediate publication on acceptance

- Open access: articles freely available online

- High visibility within the field

- Retaining the copyright to your article

Submit your next manuscript at $\boldsymbol{\wedge}$ springeropen.com 